\title{
Role of Chitinase and Other Lysosomal Enzymes of Coprinus lagopus in the Autolysis of Fruiting Bodies
}

\author{
By W. ITEN AND P. MATILE \\ Department of General Botany, Swiss Federal Institute of Technology, \\ Zürich, Switzerland
}

(Accepted for publication 26 January 1970)

SUMMARY

The autolysis of mature fruiting bodies of Coprinus lagopus is caused by the degradation of cell walls. This process is accomplished by the action of chitinases which are newly formed shortly before spore release begins. Chitinase activity is localized intracellularly in vacuoles together with other hydrolytic enzymes. It is released into the wall upon cessation of metabolic activity in senescing gills.

\section{INTRODUCTION}

Members of the genus Coprinus are characterized by a rapid autolysis of the mature fruiting body. Elucidation of such a lytic process should involve a study of the relevant hydrolytic enzymes as well as their intracellular localization and function in the living organism. Constitutive digestive enzymes which eventually autolyse yeasts are localized in the vacuoles (Matile \& Wiemken, 1967). Thus, autolysis appears to represent an extreme case of intracellular lysis which normally takes place in a special compartment, the lysosome (see Matile, 1969). The present study concerns the intracellular localization of hydrolases in Coprinus lagopus. Special attention has been paid to the role of lysosomes and lysosomal enzymes in autolysis in mature gills.

\section{METHODS}

A strain of Coprinus lagopus Fr. isolated from horse-dung was used. Mycelia were grown in a liquid medium containing, in g./1.: glucose, 10; Hammerstencasein, 2.5; $\mathrm{KH}_{2} \mathrm{PO}_{4}, 2 ; \mathrm{MgSO}_{4} .7 \mathrm{H}_{2} \mathrm{O}, 0.2$; thiamine, 0.005 and trace elements [in mg./1.: $\mathrm{Fe}\left(\mathrm{NH}_{4}\right)\left(\mathrm{SO}_{4}\right)_{2} \cdot 6 \mathrm{H}_{2} \mathrm{O}, 5 ; \mathrm{ZnSO}_{4} \cdot 7 \mathrm{H}_{2} \mathrm{O}, 25 ; \mathrm{CuSO}_{4} \cdot 5 \mathrm{H}_{2} \mathrm{O}, \mathrm{I} \cdot 25 ; \mathrm{MnSO}_{4} \cdot \mathrm{H}_{2} \mathrm{O}, 0 \cdot 25$; $\left.\mathrm{H}_{3} \mathrm{BO}_{3}, 0.25 ; \mathrm{Na}_{2} \mathrm{MoO}_{4} \cdot \mathrm{H}_{2} \mathrm{O}, 0.25\right] .500 \mathrm{ml}$. conical flasks with $200 \mathrm{ml}$. medium were inoculated with a suspension of spores and agitated on a reciprocal shaker at $28^{\circ}$. Fruiting bodies were obtained in cultures in glass cylinders (10 cm. diameter) containing $100 \mathrm{ml}$. of solid medium containing (g./l. water): malt extract, I0; Difcoyeast extract, 4; glucose, 4; Difco-agar, Io. A piece of vegetative mycelium of about I cm$~^{2}$ grown on a solid medium was placed on this nutrient agar and an incandescent lamp (tungsten filament bulb, $75 \mathrm{~W}$ ) was installed $80 \mathrm{~cm}$. from the culture vessel. Illumination of the cultures for $8 \mathrm{hr} /$ day at $28^{\circ}$ led to the first fruiting bodies maturing 7 days after inoculation.

Fractionation. Cell-free extracts used for preparing subcellular particles and for the determinations below were obtained by squeezing gills with pestle and mortar in a sorbitol medium (0.3 M-sorbitol, $0.02 \mathrm{M}$-tris-HCL buffer $\mathrm{pH} \mathrm{7.4,} \mathrm{I} \mathrm{mM-EDTA).}$ 
Quartz was added for extracting vegetative mycelia. No buffer was added if extracts were used only for the determinations below.

Preparation of vacuoles. Cell-free extracts were centrifuged at a low speed (Io min. $500 \mathrm{~g}$ ) which removed unbroken cells and walls. A mitochondrial fraction containing vacuoles was obtained by differential centrifugation at $10,000 \mathrm{~g}$ for $10 \mathrm{~min}$. Two postmitochondrial fractions sedimented at $40,000 \mathrm{~g}$ (10 min.) and $150,000 \mathrm{~g}$ (30 min.) respectively. The final supernatant represented the soluble fraction. The sediments were washed once with sorbitol medium. Vacuoles were isolated using isopycnic gradients of Ficoll (Pharmacia Uppsala) ranging from $20 \%$ (w/v) Ficoll (in $0.2 \mathrm{M}$-sorbitol) to $0.5 \mathrm{M}$-sorbitol. The gradients $(4.5 \mathrm{ml}$.) were loaded with $\mathrm{I} \cdot 0 \mathrm{ml}$. of mitochrondrial fraction suspended in sorbitol medium. $0.01 \%(\mathrm{w} / \mathrm{v})$ Triton X-I00 was added to prevent aggregation of particles. Centrifugation was carried out for $2 \mathrm{hr}$ at 39,000 rev./min. in a Spinco SW 39 rotor. A large proportion of vacuoles was trapped at the top of the Ficoll gradients. These particles were purified by flotation in the presence of $8 \%$ $(\mathrm{w} / \mathrm{v})$ Ficoll (in $0.3 \mathrm{M}$-sorbitol) through a layer of $6 \%(\mathrm{w} / \mathrm{v})$ Ficoll prepared in $0.3 \mathrm{M}-$ sorbitol.

Table I. Lysosomal enzymes of Coprinus: $p H$-optima and references to the conditions of assay

\begin{tabular}{|c|c|c|c|c|}
\hline Enzyme & Substrate & Buffer & pH optimum & Remarks \\
\hline Acid protease & Haemoglobin & Acetate & $2 \cdot 5$ & $\begin{array}{l}\text { Acid-soluble pro- } \\
\text { ducts determined } \\
\text { according to } \\
\text { Lowry } \text { et al. } \\
\text { (I95I) }\end{array}$ \\
\hline Alkaline protease & Casein & Carbonate & $9 \cdot 5$ & - \\
\hline$\beta$-Glucosidase & $\begin{array}{c}p \text {-Nitrophenyl- } \\
\beta \text {-Glucoside }\end{array}$ & Acetate & $5 \cdot 0$ & $\begin{array}{l}\text { Formation of } \\
p \text {-nitrophenol }\end{array}$ \\
\hline Phosphatase & $\begin{array}{l}p \text {-Nitrophenyl } \\
\text { phosphate }\end{array}$ & Acetate & $5 \cdot 0$ & - \\
\hline RNase & $\begin{array}{l}\text { Purified } \\
\text { yeast RNA }\end{array}$ & Acetate & $5 \cdot 2$ & $\begin{array}{l}\text { u.v. Absorbancy of } \\
\text { acid-soluble } \\
\text { products }\end{array}$ \\
\hline Chitinase & $\begin{array}{l}\text { Purified cell } \\
\text { walls from } \\
\text { gills of } \\
\text { Coprinus }\end{array}$ & Acetate & $5 \cdot 0$ & $\begin{array}{l}\text { Method described } \\
\text { in the text }\end{array}$ \\
\hline
\end{tabular}

Determinations. Activities of hydrolytic enzymes were measured at $37^{\circ}$ using the substrates and buffers listed in Table I. Chitinase from Coprinus hydrolyzes the chitin present in extensively purified cell walls from gills of Coprinus fruiting bodies isolated according to Crook \& Johnston (1962). Dry wall powder (25 mg.) suspended in $1 \mathrm{ml}$. $0 \cdot \mathrm{I} \mathrm{M}$-acetate buffer $\mathrm{pH} 5^{\circ} \mathrm{O}$ was the substrate. The reaction was stopped by heating $2 \mathrm{~min}$. at $100^{\circ}$. After centrifuging down the insoluble material, $\mathrm{N}$-acetylglucosamine was determined according to Reissig, Strominger \& Leloir (1955). Alternatively, reducing groups were measured using the reagent of Nelson (I954). In controls, either walls or enzyme were omitted. Cytochrome oxidase, succinic dehydrogenase and aldolase activities were assayed by standard procedures.

For protein and RNA, samples of extracts were treated with $10 \%(w / v)$ TCA. The precipitated protein was determined according to Lowry, Rosebrough, Farr \& Randall (I95I), and RNA by the orcinol reagent of Schneider (1957). 
Isolated walls hydrolysed with $5 \mathrm{~N}-\mathrm{HCl}$ for $5 \mathrm{hr}$ at $100^{\circ}$ were qualitatively analysed on thin layers of Kieselgur impregnated with $0.02 \mathrm{M}$-sodium acetate. The solvent was a mixture of 6 vol. ethylacetate and 4 vol. of isopropanol-water (2:1 v/v). Anisaldehyde was used as the spray reagent (Stahl, 1962).

\section{Table 2. Development of the fruiting body of Coprinus lagopus under the experimental conditions used}

The zero point of the time axis coincides with the commencement of spore release, an event which can be easily observed.

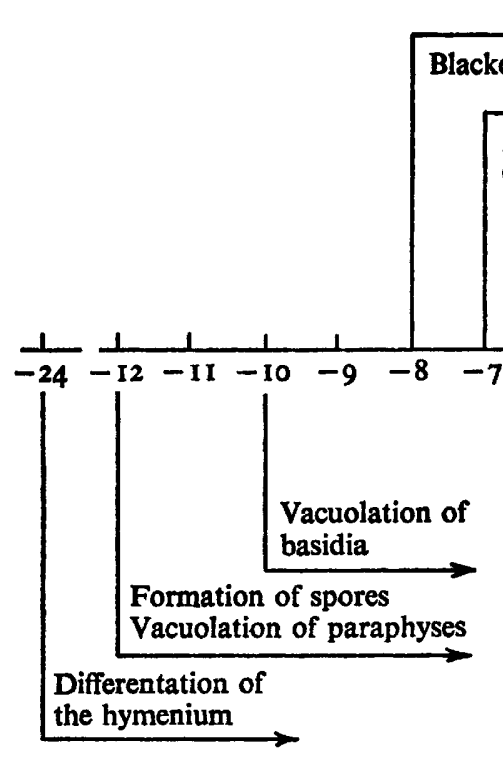

Macroscopical events

lackening of the pileus

Rapid elongation of the stipe $\quad$ Release of spores Opening of the pileus Autolysis of gills

Autolysis of gills completed

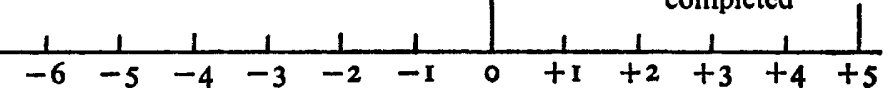

Vacuolation of basidia and

Hours paraphyses completed

Microscopical events

\section{RESULTS}

Morphology of the developing fruiting body. Mycelia of Coprinus lagopus placed on solid nutrient media developed into mats about $5 \mathrm{~cm}$. in diameter within 5 days. At this time small primordia were formed which subsequently developed into fruiting bodies. This process has been described in detail by Buller (1924) and Borriss (1934). The macroscopical and microscopical events which were observed under the conditions used are summarized in Table 2. The zero point of the time axis is the time at which the first spores were released.

The first spores released originated from the edges of the gills adjacent to the stipe. Soon after a region released its spores its autolysis began. The resulting liquor was sucked by capillary forces into the intact regions of the gills where it dissolved the cells. A zone of spore release followed by a zone of autolysis moved peripherally and reached the edge of the pileus within about $5 \mathrm{hr}$.

Physiology of the developing fruiting body. Slices of intact gills were placed in drops of liquor from autolysing fruiting bodies and incubated at $25^{\circ}$. It appeared that the cell walls were degraded. This process could be followed in the phase contrast microscope. It was completed within about $3 \mathrm{hr}$. By using the digestive capacity of autolysate liquor, naked protoplasts could be prepared from undifferentiated hymenia. If young gills (corresponding to a developmental stage of $-20 \mathrm{hr}$; Table 2) were first incubated 
with autolysate for $2 \mathrm{hr}$ and then gently squeezed, protoplasts containing two nuclei and two large vacuoles were released. They originated from hymenial cells which would later have differentiated into paraphyses. We could not prepare protoplasts from vegetative mycelia by this technique; the reason is unknown. The walls of gills and

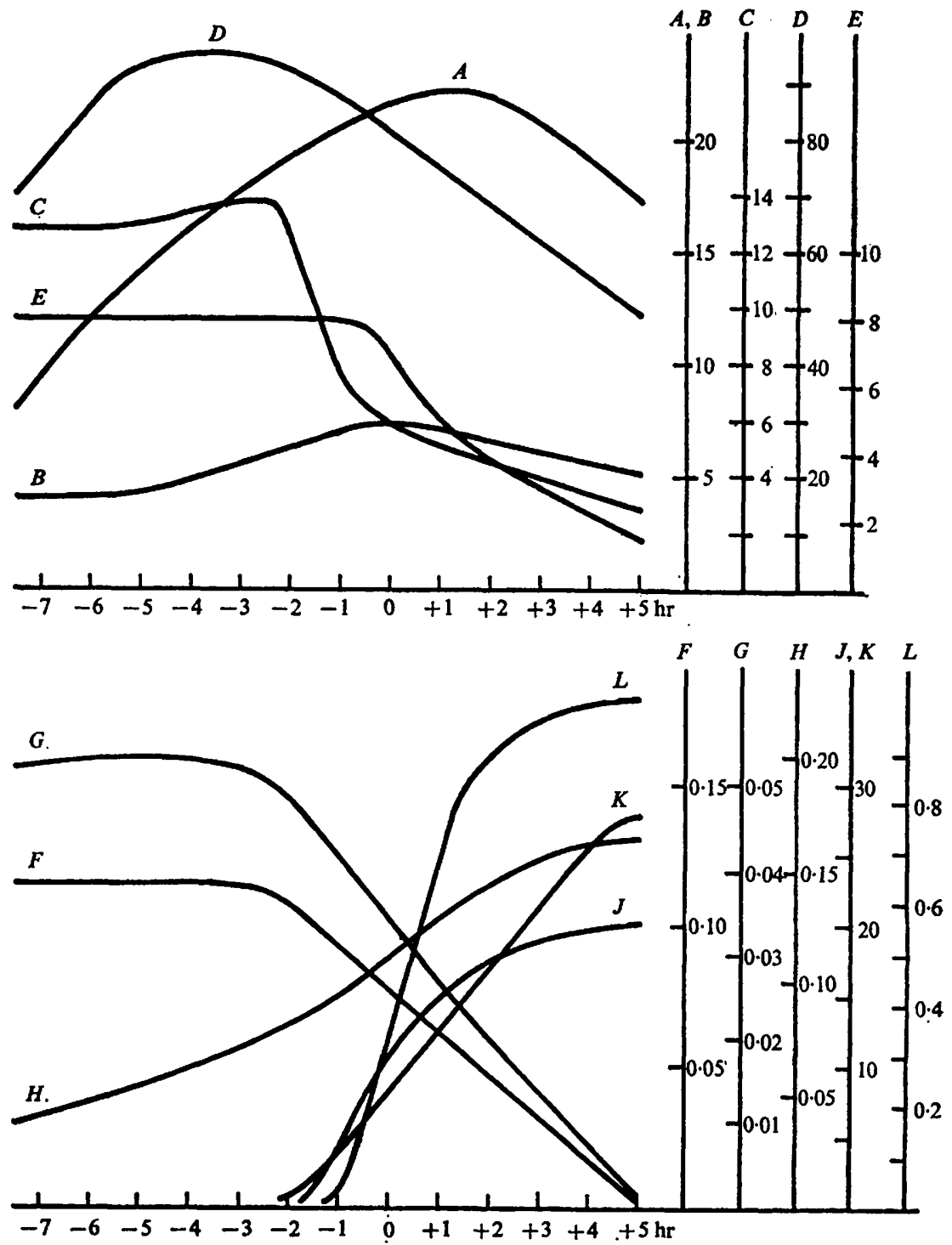

Fig. I. Changes of some enzyme activities and compounds in cell-free extracts from gills during the development of fruiting bodies. Samples were collected at the following time points (se Table 2): $-7 \cdot 5,5,2 \cdot 2,0.5 \mathrm{hr}$ and $+5 \mathrm{hr}$ RNA and protein are given in $\mu \mathrm{g}$. $/ \mathrm{mg}$. of dry matter of the extracts. $A$, alkaline protease ( $\mu$ g. tyrosine equiv./30 min.); $B$, acid protease ( $\mu$ g. tyrosine equiv./30 min.); $C$, acid RNase ( $\mu_{\text {g. }}$ RNA/60 min.); $D$, protein $(\mu \mathrm{g}$.); $E$, RNA $\left(\mu_{\mathrm{g}}\right) ; F$, aldolase $\left(\Delta E_{20_{0}} / \mathrm{min}.\right) ; G$, cytochrome oxidase $\left(\Delta E_{\mathrm{bs} 0} / \mathrm{min}.\right) ; H$, acid $\beta$-glucosidase ( $\mu \mathrm{g}$. glucose/ro min.); $J, N$-acetylglucosamine $\left(\mu \mathrm{g}\right.$.); $K$, acid chitinase ( $\mu_{\mathrm{g}}$. $N$-acetylglucosamine/20 min.); $L$, acid chitinase; determination of reducing groups (mg. $\mathrm{N}$-acetylglucosamine equiv./20 min.). 
vegetative mycelium appear to be chemically similar: thin layer chromatography of hydrolysates revealed only glucosamine. If isolated walls were incubated with autolysate liquor, $N$-acetylglucosamine was formed. Thus, chitin is a prominent wall constituent which has, in fact, been identified by Frey (1950) in walls of Coprinus atramentarius. In addition, chitinase activity appears to be present in the autolysing fruiting bodies of $C$. lagopus.

Using a viscosimetric method Tracey (1955) demonstrated chitinase activity in Coprinus comatus. Upon incubation of $C$. lagopus cell walls with autolysate liquor the formation of total reducing groups was about 30 times more active than the production of the monomer $N$-acetylglucosamine. It thus appears that $C$. lagopus formed mainly chitinase; only low activities of chitobiase seemed to be present in the autolysing fungus.

Chitinase activity was lacking in the vegetative mycelium and young fruiting bodies. The enzyme was synthesized about $2 \mathrm{hr}$ before spores were released (Fig. I). The synthesis of chitinase proceeded rapidly for about $3 \mathrm{hr}$; thereafter the activity decreased gradually towards the end of autolysis. Fig. I also shows that, unlike chitinase, proteases and RNase were present in extracts of gills of immature fruiting bodies and also in the vegetative mycelium. The process of differentiation of fruiting bodies was characterized by an increase of protease activities towards the beginning of autolysis and by a subsequent decrease. The protein content of gills began to decrease about $3 \mathrm{hr}$ before the beginning of autolysis. Moreover, the activities of two respiratory enzymes decreased much faster than the total protein and were almost zero at the end of autolysis. Similarly the RNA content began to fall sharply at -2 to $3 \mathrm{hr}$.

Table 3. Sedimentability of alkaline protease and cytochrome oxidase in a cell-free extract from vegetative mycelium grown for $45 \mathrm{hr}$

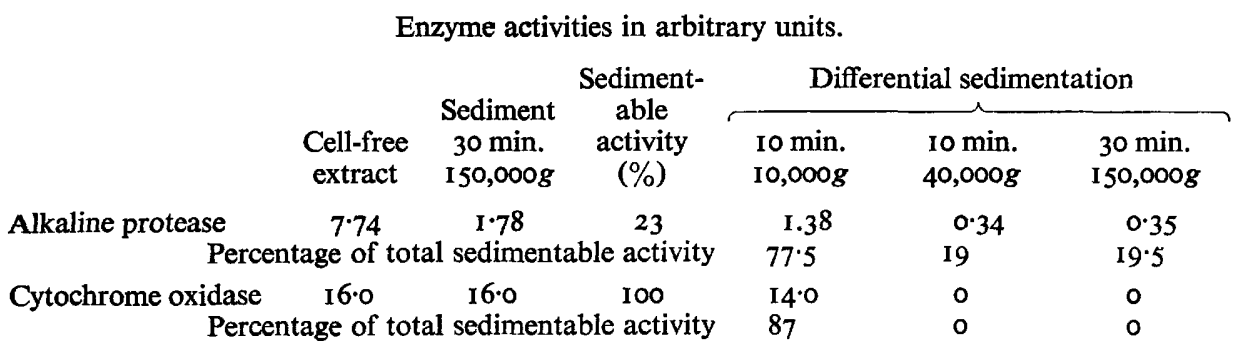

The above estimations concern a heterogeneous tissue containing cells at different stages of development; nevertheless they may reflect physiological events taking place during development of fruiting bodies. The data suggests that autolysis is not exclusively responsible for the decreasing protein and RNA contents in fruiting bodies which approach maturity. Since these events take place several hours before autolysis begins it seems to be likely that they are caused by cellular lytic processes which take place in lysosomes.

Subcellular localization of digestive enzymes. Lysosome-like structures were extracted from both vegetative mycelia and fruiting bodies. One criterion used for demonstrating the existence of lysosomes was sedimentability of hydrolases. These enzymes were partially sedimentable from extracts of vegetative mycelia but a large proportion occurred in the soluble fraction. The data in Table 3 indicate that a large 
proportion of the sedimentable activity was contained in a 'mitochondrial fraction'. Similar results were obtained with extracts from gills.

Upon centrifugation of mitochondrial particles loaded on gradients of Ficoll the activities of several lysosomal enzymes were trapped at the top of the gradient but some activity was distributed throughout the gradient (Fig. 2). If gills containing chitinase activity were used for preparing lysosomes, the distribution of this enzyme in the gradient corresponded with that of other hydrolases tested, viz. acid and alkaline protease, RNase, phosphatase and $\beta$-glucosidase. Coinciding distribution curves of chitinase and other hydrolases were also obtained upon centrifugation in density gradients of sucrose or Urografin. Thus chitinase appeared to represent a lysosomal enzyme.

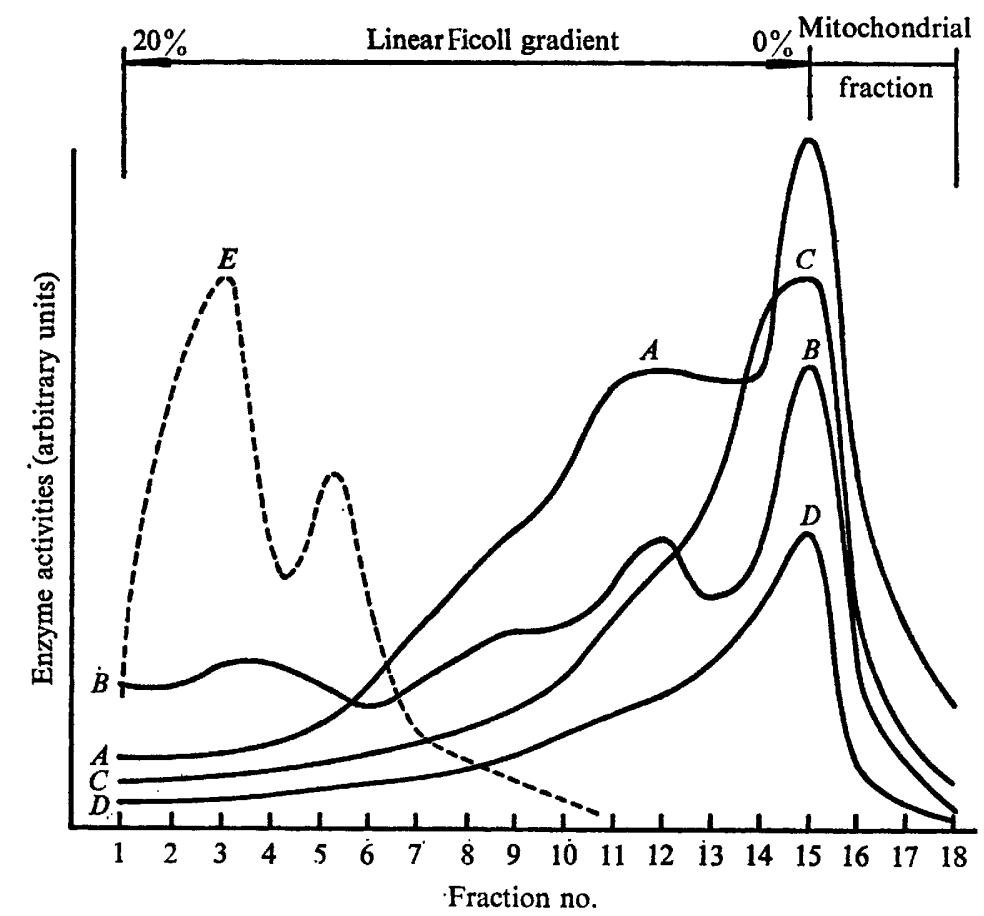

Fig. 2. Distribution of lysosomal enzymes in a linear density gradient of Ficoll. The mitochondrial fraction (suspended in $0.5 \mathrm{M}$-sorbitol medium) loaded on the gradient was obtained from an extract prepared from gills shortly before the commencement of spore release. To maintain the osmotic stabilization of particles the Ficoll gradient $(20$ to $0 \% \mathrm{w} / \mathrm{v})$ was superimposed by a sorbitol gradient $(0.2$ to $0.5 \mathrm{M})$.

Phase contrast microscopy of particles trapped at the surface of a Ficoll gradient showed vacuoles 0.5 to $4 \mu \mathrm{m}$. in diameter (Pl. Ic ). Particles present in gradient zones of higher density were smaller ( $\mathrm{I} \mu \mathrm{m}$.). To demonstrate that the enzymes were enclosed in the vacuolar structures, it was necessary to test the respective preparations for free hydrolase activity. Some activity appeared to be free when osmotically stabilized particles were incubated, but the disintegration of these structures previous to incubation resulted in a doubling of the activities measured. If the vacuoles were further purified by flotation in Ficoll the percentage of latent activity increased markedly (Table 4). It thus seems that the vacuoles represent lysosomes. The relatively 
high proportion of hydrolase activities present in the soluble fraction was undoubtedly due to rupture of large vacuoles during grinding or squeezing of hyphae. Extracts from young mycelia, grown for $45 \mathrm{hr}$, contained about $23 \%$ of sedimentable protease activity, as compared with mycelia grown for Io days which yielded only II.4\% protease activity. The number of large vacuoles which cannot be extracted in intact form is much larger in old than in young hyphae. The micrograph in Pl. I $a, b$ shows that the first small vacuoles occur at about $100 \mu \mathrm{m}$. from the growing tip of the hypha. With increasing age the vacuoles gradually inflate and at about $2 \mathrm{~mm}$. from the tip the cells appear to be completely vacuolated. The size of the isolated vacuoles suggests that only a zone between 100 and $500 \mu \mathrm{m}$. from the tip yielded vacuoles extractable under the conditions used. A similar situation must be assumed in lamellar hyphae.

\section{Table 4. Latency of acid phosphatase and alkaline protease in vacuoles isolated from vegetative mycelium}

The particles were incubated isotonically in substrate containing $0.5 \mathrm{M}$-sorbitol. Total activities were measured using ultrasonicated particles. The time course of the reaction $\left(20 \mathrm{~min} .25^{\circ}\right)$ in both untreated and sonicated preparations was strictly linear. Enzyme activities in arbitrary units.

\begin{tabular}{|c|c|c|c|c|c|c|c|c|}
\hline \multirow[b]{3}{*}{$\begin{array}{l}\text { Cell-free extract } \\
\text { Crude vacuoles }\end{array}$} & \multicolumn{3}{|c|}{ Acid phosphatase } & & \multicolumn{4}{|c|}{ Alkaline protease } \\
\hline & $\begin{array}{c}\text { Free } \\
\text { activity }\end{array}$ & $\begin{array}{l}\text { Total } \\
\text { activity }\end{array}$ & & $\begin{array}{l}\text { ty } \\
(\%)\end{array}$ & $\begin{array}{c}\text { Free } \\
\text { activity }\end{array}$ & $\begin{array}{l}\text { Total } \\
\text { activity }\end{array}$ & & $\begin{array}{l}\text { nt } \\
\text { ity } \\
(\%)\end{array}$ \\
\hline & $\begin{array}{l}0.254 \\
0.037\end{array}$ & $\begin{array}{l}0.266 \\
0.084\end{array}$ & $\begin{array}{l}0.012 \\
0.047\end{array}$ & $\begin{array}{l}4 \cdot 5 \\
56\end{array}$ & $\begin{array}{r}\text { I I I } \cdot 3 \\
\text { I } 8 \cdot 3\end{array}$ & $\begin{array}{r}\text { I } 14.0 \\
35^{\circ} \mathrm{I}\end{array}$ & $\begin{array}{r}2.7 \\
16.8 \\
\end{array}$ & $\begin{array}{r}2 \cdot 4 \\
4^{8}\end{array}$ \\
\hline
\end{tabular}

Isolated vacuoles could also be identified by freeze-etching. The fine structure of their membrane corresponded with that of vacuoles observed in situ ( $\mathrm{Pl}$. I $d, e)$.

The role of vacuoles in intracellular lytic processes not only appears from their content of hydrolytic enzymes but also from a feature of the tonoplast which appears from the examination of freeze-etchings. Tonoplasts often show invaginations which encapsulate cytoplasmic material ( $\mathrm{Pl} .2 a, c)$. This process results in the formation of intravacuolar vesicles which are occasionally very numerous in vegetative and hymenial cells (P1. 2b). They can also be observed in isolated vacuoles by freeze-etching or phasecontrast microscopy. The relatively high amount of protein present in preparations of isolated vacuoles is probably due to cytoplasmic material in the cell sap. Intravacuolar vesicles probably decay soon after cleavage of their membrane from the tonoplast; subsequently their cytoplasmic content would be degraded by the action of lysosomal enzymes.

\section{DISCUSSION}

The lysosomal enzymes localized in vacuoles of Coprinus fall into two categories. A first group of enzymes comprises hydrolases which are present throughout the life cycle of the fungus. Acid and alkaline protease, RNase, phosphatase and $\beta$ glucosidase have been found in vacuoles isolated from vegetative mycelium as well as from gills. Coprinus vacuoles represent a type of lysosome which does not contain acid hydrolases exclusively; the alkaline protease has an even more pronounced activity than its acid counterpart. The group of enzymes mentioned above appears to 
be involved in lytic processes which represent a conspicuous feature of metabolism. The cytoplasm of old hyphae is almost completely replaced by large vacuoles; its mobilization takes place during the process of vacuolation which begins in a zone near the tip of the hyphae. The mechanism of formation of digestive vacuoles seems to correspond essentially to that found in other organisms such as root-tip cells (Matile \& Moor, 1968) and yeast (Matile, 1970). It involves a pinocytosis-like activity of the tonoplast that results in the formation of intravacuolar vesicles which are presumed to be labile. After the decay of these structures their cytoplasmic content is digested by the action of the vacuolar hydrolases.

A second group of lysosomal enzymes is represented by chitinolytic enzymes, mostly chitinase. They seem to have no function in intracellular digestion since they are synthesized shortly before autolysis begins in gills. It is not yet clear whether the cells actively secrete these enzymes into the walls and thus induce their own autolysis or whether passive release occurs from cells whose metabolic activity has ceased completely. The second possibility seems to be more likely because the maturation of the fruiting body is accompanied by a rapid decrease of the activity of respiratory enzymes. This suggests that in those cells which autolyse first the respiratory activity is extinguished at the moment of spore release. The functional significance of autolysis with regard to the release of spores in Coprinus has been extensively described by Buller (1924).

Certain hydrolases belonging to the first group have a dual, intracellular and extracellular function. If vegetative mycelia are nourished with a proteinaceous nitrogen source such as casein the secretion of acid and alkaline protease into the culture medium can be observed. The release of hydrolases then is most probably not accomplished by autolysing cells. Active secretion via secretory granules is more likely involved as has been observed in Neurospora crassa (Matile, 1965; Matile, Jost \& Moor, 1965).

We should like to thank Dr E. Müller for kindly supplying the Coprinus strain used in this study, and also Professor H. Moor and Miss C. M. Berger for preparing the freeze-etchings.

\section{REFERENCES}

BORRIss, H. (1934). Beiträge zur Wachstums- und Entwicklungs Physiologie von Coprinus lagopus. Planta 22, 28.

Buller, A. H. R. (1924). The production and liberation of spores in hymenomycetes. In Researches on Fungi, vol. 3. London: Longmans (reprinted 1958).

Crook, E. M. \& Johnston, I. R. (1962). The qualitative analysis of the cell walls of selected species of fungi. Biochemical Journal 83, 325.

FreY, R. (1950). Chitin und Zellulose in Pilzzellwänden. Bericht der Schweizerischen Botanischen Gesellschaft 60, 199.

Lowry, O. H., Rosebrough, N. J., FARR, A. L. \& RANDall, R. J. (195I). Protein measurement with Folin phenol reagent. Journal of Biological Chemistry 193, 265.

MatiLE, P. (1965). Intrazelluläre Lokalisation proteolytischer Enzyme von Neurospora crassa. I. Funktion und subzelluläre Verteilung proteolytischer Enzyme. Zeitschrift für Zellforschung und Mikroskopische Anatomie 65, 884.

Matile, P. (1969). Plant lysosomes. In Lysosomes in Biology and Pathology, pp. 406-30. Edited by J. T. Dingle \& H. B. Fell. Amsterdam: North Holland Publishing Company.

MAtILE, P. (1970). Recent progress in the study of yeast cytology. Proceedings of the Second International Symposium on Yeast Protoplasts, Brno. (In the Press.)

MATILE, P. \& MOOR, H. (I968). Vacuolation: origin and development of the lysosomal apparatus in root tip cells. Planta 80,159 . 
Journal of General Microbiology, Vol. 6I, No. 3

Plate I
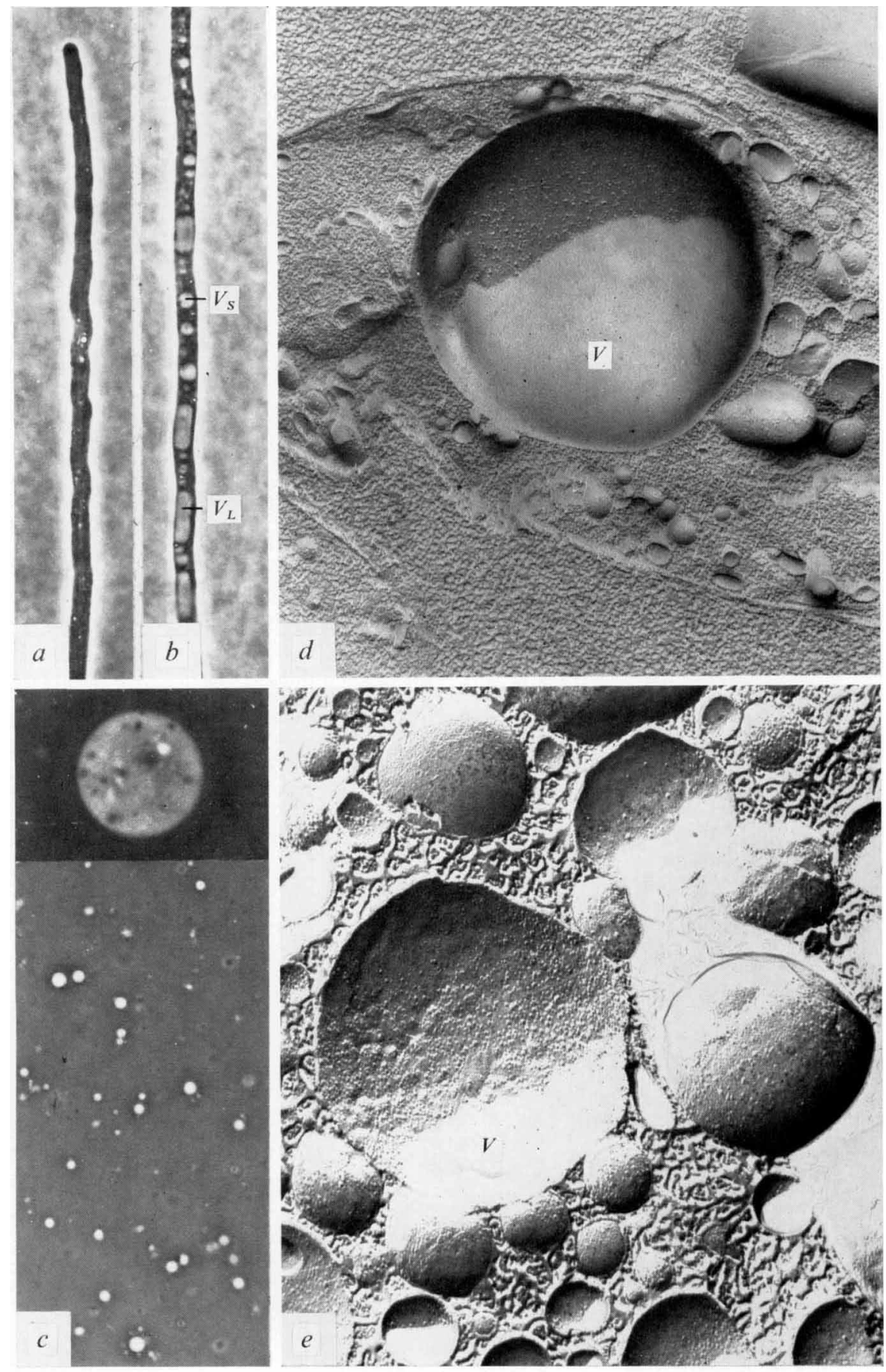
Journal of General Microbiology, Vol. 6I, No. 3

Plate 2

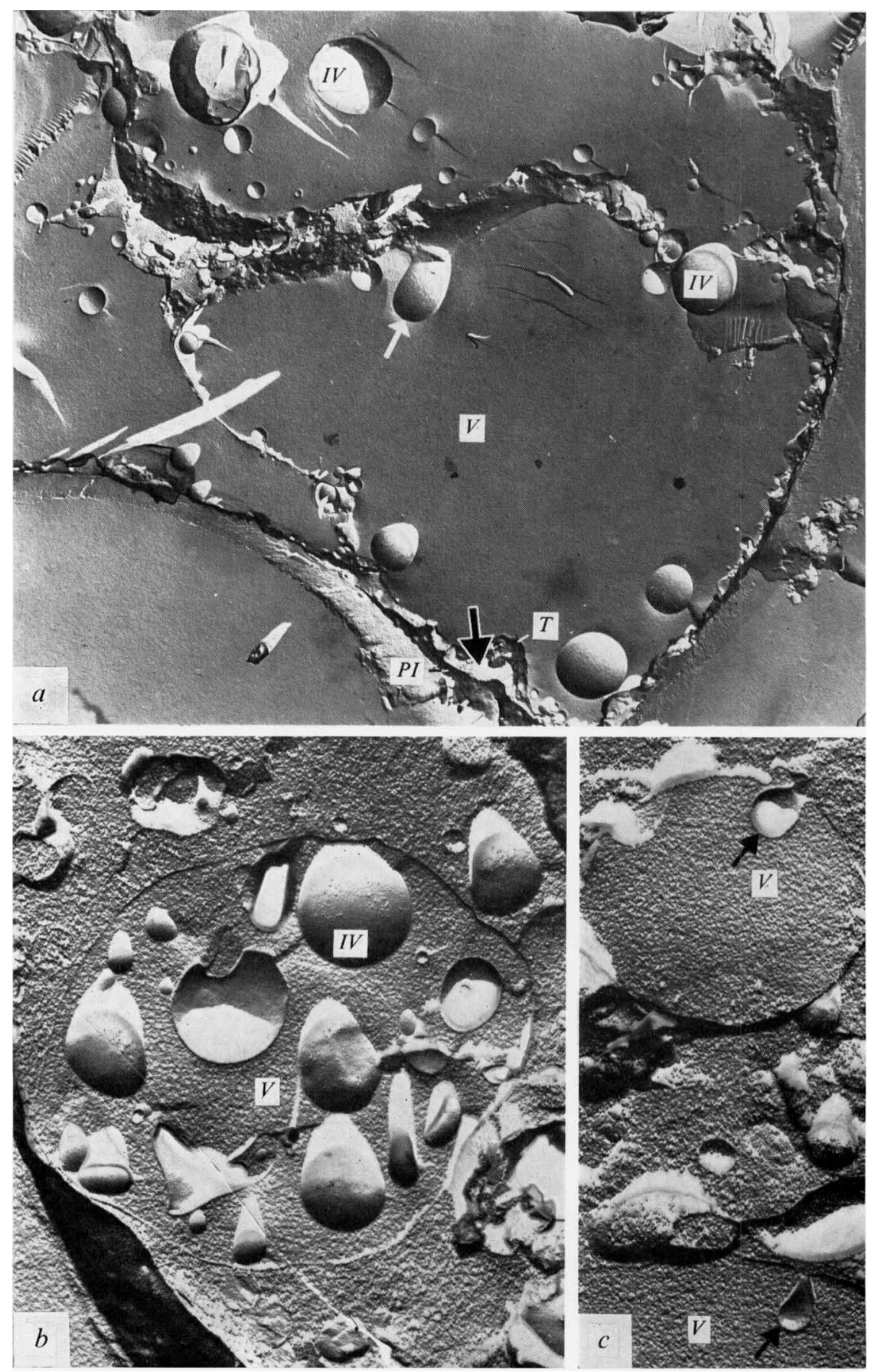

W. ITEN AND P. MATILE 
Matile, P. \& Wiemken, A. (1967). The vacuole as the lysosome of the yeast cell. Archiv für Mikrobiologie 56, 148.

Matile, P., Jost, M. \& Moor, H. (1965). Intrazelluläre Lokalisation proteolytischer Enzyme von Neurospora crassa. II. Identifikation von proteasehaltigen Zellstrukturen. Zeitschrift für Zellforschung und Mikroskopische Anatomie 68, 205.

Nelson, N. (1944). A photometric adaptation of the Somogyi method for the determination of glucose. Journal of Biological Chemistry 153, 375.

Reissig, J. L., Strominger, J. J. \& Leloir, L. F. (1955). A modified colorimetric method for the estimation of $N$-acetylamino sugars. Journal of Biological Chemistry 217, 959.

SCHNEDER, W. C. (1957). Determination of nucleic acids in tissues by pentose analysis. Methods in Enzymology 3, 680 .

StaHL, E. (1962). Dünnschichtchromatographie. Berlin: Springer-Verlag.

TRACEY, M. V. (1955). Chitinases in some basidiomycetes. Biochemical Journal 6r, 579.

\section{EXPLANATION OF PLATES}

Plate I

$a, b$. Vegetative hyphae grown on a microscope slide covered with a film of solid medium, $a$, Tip of a hypha; $b$, adjacent section of the same hypha. Note the small vacuoles $\left(V_{s}\right)$ which correspond to the isolated vacuoles. Larger vacuoles $\left(V_{L}\right)$ are destroyed upon homogenization. (Phase contrast, $\times 460$.) $c$, Vacuoles isolated from vegetative mycelium (phase contrast, $\times 440$ ). Insert shows vacuole containing numerous intravacuolar vesicles $(\times 1400)$. $d$, Freeze-etching of a vegetative hypha. Note the vacuole $(V)$ viewed on the outer surface of the tonoplast. $e$, Freeze-etched preparation of isolated vacuoles $(\times 36,000)$.

\section{Plate 2}

Freeze-etchings of gills at the stage of spore formation ( $12 \mathrm{hr}$ before beginning of spore release). $a$, Highly vacuolated cells; the central vacuole $(V)$ occupies almost all the cell. A thin layer of cytoplasm (black arrow) can be recognized between the plasmalemma $(P l)$ and the tonoplast $(T)$. The vacuole contains a number of intravacuolar vesicles $(I V)$. The white arrow points to an invagination of the tonoplast which results in the formation of an intravacuolar vesicle $(\times 4600)$. $b$, Vacuole containing numerous intravacuolar vesicles $(\times 20,600)$. $c$, Formation of intravacuolar vesicles; vacuoles showing invaginations (arrows) of the tonoplast $(\times 27,600)$. 